\title{
Environmental Performance Information Disclosure of A-share Listed Companies
}

\author{
Jiu-Fang TANG ${ }^{1, a,{ }^{*}}$, Xue-Zhi WANG ${ }^{1, b}$, Xiao-Hua $\mathrm{LIN}^{2, \mathrm{c}}$, Peng-Fei $\mathrm{LI}^{3, \mathrm{~d}}$ \\ ${ }^{1}$ Business School, Hunan University of Science and Technology,Xiangtan Hunan, China \\ ${ }^{2}$ Business School, Wuhan Yangtze Business University, Wuhan Hubei, China \\ ${ }^{3}$ School of Economics Management, China University of Geosciences, Wuhan Hubei, China \\ ajftang2005@163.com, [512656280@qq.com, '9xhznmd @gmail.com, ${ }^{\text {b }}$ pfli@vip.sina.com \\ ${ }^{*}$ Corresponding author
}

Keywords: Environmental award, Social Responsibility Report, Environmental Performance Information Disclosure.

\begin{abstract}
The paper sample period covered the years 2007-2011 A-share listed companies of Chinese chemical industry. We used an environmental performance disclosure index and evaluated the environmental performance disclosure information (EPDI) according to the Sustainability Reporting Guidelines Version 3. 0 (G3) developed by the Global Reporting Initiative (GRI) in 2006. Then we developed a multivariate linear regression to test determinants of EPDI level. The results showed that EPDI level was critically low; Environmental award and listed place of companies were significantly positive correlated to EPDI. The EPDI level of listed companies in Shanghai Stock Exchange was better than that of Shenzhen Stock Exchange. Company size and registration place of companies were positive correlation to EPDI, but failed to pass the significant test. However, the development capability, EPS, and liability degree were negative correlation to EPDI level, and also failed to pass the significant test.
\end{abstract}

\section{Introduction}

Shenzhen Stock Exchange (SZSE), one of Chinese stock markets, issued Shenzhen Stock Exchange guidelines on corporate social responsibility for listed companies in 2006. The guidelines advocated listed companies bearing social responsibilities for the first time and encouraged enterprises to voluntarily disclose information about environmental pollution and abide the Sustainability Reporting Guidelines by GRI, which was the international standard preparation and disclosure of social responsibility report. Shanghai Stock Exchange (SHSE) announced social responsibility report of listed companies and internal control self-assessment in 2008. Shenzhen Stock Exchange demanded that listed companies of Shenzhen 100 Index in 2009 must disclose social responsibility information. The present paper involved the listed companies of chemical industries in the period of 2007-2011 and used multiple regression models to research factors of environmental performance information of listed company.

The present paper is organized as follows: firstly, Section 2 described the relevant literature; secondly, Section 3 describes the data and develops the methodology and hypotheses; thirdly, Section 4 gives the empirical results and their interpretation; finally, Section 5 concludes the paper.

\section{Literature Review}

Adam Smith mentioned corporate social responsibility (CSR) in his Wealth of Nations, and believed that profit maximization was the CSR. However, American scholars hotly debated about CSR. Milton Friedman, FA Hayek (2000) firmly opposed to bear CSR. E. Merrick Dodd (1932), HR Bowen (1953), Harold Kuntz (1993), favored CSR and pointed view business ethics and welfare economics. Carroll (1979) believed that CSR should involved financial responsibility, legal responsibility, ethical responsibility, and charitable responsibility. Brummer (1991) supposed that 
CSR should be tied with economic responsibility, legal responsibility, and moral responsibility. Ingram (1978) first used to test capital markets about CSR from 1969 to 1975 with Fortune 500 companies as samples. The results showed that monetary CSR of the annual rate of return was higher than the non-monetary CSR of portfolio. Empirical studies of Guo (2007) showed that more social responsibility and sustainable development strategy portfolio consisting of companies in financial income had become more stable and stronger hedge portfolio. Shen (2008) investigated the petrochemical plastics industry of A-share companies during the period of 1999-2004. They found that CSR by Chinese listed companies had value correlation, and there was a significant positive correlation between the disclosed quantity and quality, and stock profits.

Research organizations of environmental pollution in Canada(Pollution Probe,2005)defined corporate environmental responsibility from three aspects. Firstly, environmental responsibility was favorable to sustained growth of economy and had beneficial influence on environment and society; secondly, environmental responsibility was in accordance with raw materials of ecological condition and system of energy management; thirdly, effectively participation of stakeholders realized transparency of environmental information. Clarkson(2008)studied 165 companies in five industries disclosure environmental information according to GRI (second edition) Guide released CSR on U.S., and found that there was a significant positive correlation between disclosure of environmental information and environmental performance. He (2010) and Tang (2012) found that listed company size was positive correlation to level of information disclosure.

\section{Data and Methodology}

\section{$A$. Date and Sample}

We chose the listed companies of chemical industry as research samples, which covered the years of 2007-2011. We acquired 122 samples from 218 listed companies belong to SZSE and SHSE. We searched annual reports, social responsibility report, and relevant information of the corporate in 2007-2011. Then, we categorized the disclosed contents, and carried out related statistics. The data were derived from China Securities Regulatory Commission, and other related financial data were originated from CSMAR. In order to reduce the deviation between the estimated value of explanatory variable and residual term, we used cross-section data of different years to expand samples and improve estimation precision.

Table 1 listed the disclosure situation of sample enterprises. We found that CSR was critically low. Especially, in 119 listed companies of chemical industry, there were only one company disclosed CSR in 2007 and the disclosure ratio was 0.84\%. Likewise, in 40 small and medium enterprises (SMEs), there was only one company revealed CSR. In 2011, in the 218 listed companies of chemical industry, the disclose ratio increased to $18.81 \%$. However, in the 31 venture enterprises, only four enterprises disclosed CSR in 2011.

Table 1 The number of investigated companies and disclosed CSR

\begin{tabular}{l|l|l|l|l|l}
\hline items & 2007 & 2008 & 2009 & 2010 & 2011 \\
\hline Total & 119 & 133 & 138 & 183 & 218 \\
\hline Disclosed companies & 1 & 23 & 24 & 33 & 41 \\
\hline SMEs number & 40 & 39 & 42 & 73 & 87 \\
\hline Disclosed companies & 1 & 7 & 6 & 7 & 12 \\
\hline Venture number & 0 & 0 & 2 & 15 & 31 \\
\hline Disclosed companies & 0 & 0 & 0 & 2 & 4 \\
\hline Disclosure percentage (\%) & 0.84 & 17.29 & 17.39 & 18.03 & 18.81 \\
\hline
\end{tabular}

After arranging the disclosed contents, we categorized the relevant CSR, and the disclosed items were shown in Table 2. The waste zero-emissions means one of waste water, gas and residue were zero-emissions. Third-party audit can be the audit of the National Audit Office, or monitor of local environmental protection bureau, or the public On-line monitoring environmental protection 
information. Only one enterprise had passed ISO9001 Quality System in 2007. In 2008, two enterprises issued information about waste zero-emission. In 2010, twenty- two enterprises had passed ISO; seven enterprises invested in field of environmental protection; fifteen enterprises got environmental awards; one enterprise was punished with huge environmental fines; five companies have been certified by third-party environmental certification.

Corporate social responsibility reports were irregular. Only one enterprise disclosed items according to the Sustainability Reporting Guidelines Version 3. 0 (G3) in 2006, whereas the others disclosed items was according to SZSE or SHSE guidelines.

\section{B. Methodology}

Our goal is to model the response of EPDI level to several factors including scale (SIZE), development ability (GROWTH), corporate profitability (EPS), financial leverage (LEV), listed Place (LIST), and registration place (PLACE). Therefore, the following multivariate linear regression model is employed for testing EPDI as a function of predictor variable values:

$E P D I_{i}=\beta_{0}+\beta_{1} E P S_{i}+\beta_{2} G R O W T H_{i}+\beta_{3} S I Z E_{i}+\beta_{4} R E W A R D_{i}+\beta_{5} L E V_{i}+\beta_{6} L I S T_{i}+\beta_{7} P L A C E_{i}+\lambda$

Table 2 The number of companies disclosed CSR items

\begin{tabular}{l|l|l|l|l|l}
\hline \multicolumn{1}{c|}{ items } & 2007 & 2008 & 2009 & 2010 & 2011 \\
\hline ISO & 6 & 16 & 20 & 36 & 57 \\
\hline Investment in environmental protection & 11 & 32 & 21 & 81 & 108 \\
\hline Water recycling & 2 & 1 & 2 & 3 & \\
\hline Waste zero-emissions & 1 & 5 & 2 & 2 & 5 \\
\hline Conservation of coal & 0 & 2 & 2 & 7 & \\
\hline Save water & 0 & 3 & 3 & 1 & \\
\hline Environmental award & 4 & 21 & 20 & 56 & 64 \\
\hline Prepared Report by G3 & 0 & 0 & 0 & 1 & \\
\hline Heavy fines & 0 & 0 & 0 & 1 & \\
\hline Included in the polluting enterprises & 0 & 0 & 0 & 1 & \\
\hline Third-party audit (monitoring) & 0 & 1 & 2 & 5 & \\
\hline
\end{tabular}

The EPDI level is the response variable. $\sum$ EPDIi /10 ratio indicate environmental performance score, and therefore are used as a quantization index of environmental performance. This paper used environmental performance index of G3 to score CSR. Firstly, CSR revealing with a detailed qualitative and quantitative analysis is assigned score 5. CSR disclosing with a less qualitative and quantitative analysis is assigned score $4,3,2$, and 1.5 , respectively. In addition, CSR revealing no environmental performance is assigned score 0. Secondly, CSR displaying detailed additional indicators of G3 is assigned score 3, and CSR disclosing less detailed additional indicators of G3 is assigned score 1.5 and 1, respectively. CSR displaying no environmental performance is assigned score 0 . If the report has an index to facilitate stakeholder environmental assessment, it is assigned an extra one point. If it is certified by third-party verification (audit) and increased credibility of CSR, it is also assigned an extra one point. The total score of EPDI is 10 points. EPS, GROWTH and LEV are explanatory variables; AWARD, SIZE, LIST and PLACE are control variables. i stands for listed companies in the period of 2007-2010. $\beta 0$ is a constant and $\beta \mathrm{i}$ is coefficients of the predictor variables. Detailed definitions of the variables are presented in Table 3.

\section{Hypothesis}

We hypothesize that there is a positive relationship between EPDI and the factors mentioned above, and get the following assumptions.

Assumption 1: The strong profitability of listed companies inclines to report environmental performance in their CSR.

Listed companies disclosed environmental performance to reveal their highly attention to the environmental protection, and implemented their environmental obligation, therefore, the 
companies undertook a small environmental risk in the sustainable management. The companies with higher profitability (EPS) had greater motivation to strictly execute environmental management standards. Consequently, they attempted to discharge zero pollution emissions, turn waste into wealth, reuse resource, save energy, reduce environmental costs, and improve environmental performance.

Table 3 Definitions of employed EPDI measures and variables

\begin{tabular}{l|l}
\hline Variable & \multicolumn{1}{|c}{ Description } \\
\hline EPDI & Environmental performance information disclosure index. \\
\hline SIZE & The logarithm of end total assets is used to measure the company size. \\
\hline GROWTH & $\begin{array}{l}\text { P/E ratio indicates the corporate expected growth rate, and therefore is used as a } \\
\text { measure of corporate development capability. }\end{array}$ \\
\hline EPS & Net income, divided by the number of shares of common stock outstanding. \\
\hline AWARD & Dummy variable equal to 1 if the company received environmental awards, 0 otherwise. \\
\hline LEV & $\begin{array}{l}\text { Asset/Liability ratio is an indicator of corporate financial level or debt level, } \\
\text { representing credit worthiness. }\end{array}$ \\
\hline LIST & Dummy variable equal to 1 if the company was listed Place in SHSE, 0 otherwise. \\
\hline PLACE & $\begin{array}{l}\text { Dummy variable equal to } 1 \text { if the company is located at the economic developed area, } 0 \\
\text { otherwise. }\end{array}$ \\
\hline
\end{tabular}

Assumption 2: The companies with strong development capability are more willing to disclose environmental performance in their CSR.

In order to gain more market share, the companies with fierce competition require continuous investment and stable suppliers. Companies with strong development capability incline to reveal their environmental performance information, which helps to construct a good environmentfriendly image and reduce financing costs.

Assumption 3: Larger companies are willing to disclose environmental performance in their CSR.

The public and control departments paid much attention to environment protection of larger companies. In order to attract investment, establish a good public image, and actively perform social responsibilities, large companies were more willing to show environmental performance.

Assumption 4: Companies which gained environmental awards incline to report environmental performance in their $C S R$.

Stakeholders, public and regulatory highly concerned about awarded companies, which was inclined to reveal environmental performance in order to maintain its good image.

Assumption 5: Listed companies with high Asset/ Liability ratio would like to voluntarily display environmental performance in their CSR.

Investors and financial institutions are important users of CSR. Disclosed environmental performance in CSR helps financial institutions to understand environmental risks of the Companies.

Assumption 6: Listed companies located in economically developed areas incline to report environmental performance in their CSR.

In general, environmental pollution was serious in economically developed areas, and the public highly concerned about the information of environmental pollution. Therefore, companies in the areas must meet stringent regulations of environmental protection departments. Local governments have carried out more stringent environmental policy. As a result, companies in economically developed areas incline to disclose environmental performance.

Assumption 7: In compared with registration place of companies in SZSE, companies in SHSE prefer to report environmental performance in their CSR.

SZSE earlier published Shenzhen Stock Exchange Guidelines on Corporate Social Responsibility (2006) for listed companies, but no specific disclosure guidelines were included. SHSE gradually released Shanghai Stock Exchange Guidelines on Disclosure Environmental Information (2008) for listed companies; Disclosure Notice on Corporate Social Responsibility and Internal Control 
self-assessment (2008) for listed companies, Preparation and Consideration on Internal Control and CSR, including Preparation Guidelines on Corporate Social Responsibility Report and related working papers. The notice strongly promoted companies to prepare the social responsibility reporting and disclosure their environmental information.

Table 4: Descriptive Statistics for Measures of Environmental Performance Information and Explanatory variables

\begin{tabular}{l|l|l|l|l|l|l}
\hline & Mean & Median & S.D. & S.E. & Minimum & Maximum \\
\hline EPDI & 0.3321 & 0.3000 & 0.1307 & 0.0132 & 0.1500 & 0.7000 \\
\hline SIZE1 & 21.97 & 22.036 & 1.150 & 0.116 & 19.227 & 24.140 \\
\hline GROWTH & 3.872 & 3.026 & 2.808 & 0.284 & -1.797 & 15.237 \\
\hline EPS & 0.5090 & 0.3126 & 0.7635 & 0.0771 & -0.8670 & 5.8932 \\
\hline lEV & 0.4887 & 0.4898 & 0.3110 & 0.0314 & 0.0896 & 2.4008 \\
\hline AWARD & 0.4286 & 0.0000 & 0.4974 & 0.0502 & 0.0000 & 1.0000 \\
\hline LIST & 0.5000 & 1.0000 & 0.5026 & 0.0508 & 0.0000 & 1.0000 \\
\hline PLACEL & 0.5204 & 1.0000 & 0.5022 & 0.0507 & 0.0000 & 1.0000
\end{tabular}

Table 4 presented descriptive statistics of the sample data. The multivariate linear regression predicted that the response variable EPDI was 0.3321 based on the 98 samples. This fact indicated that CSR of Chinese chemical industry did disclose related environmental performance, but the disclosure level was relatively low.

\section{Empirical Results}

The response variable is logarithm of EPDI in multivariate linear regression model. Table 5 shows the results derived from multivariate linear regression model. The first column corresponds to the estimated parameter. The second column gives the standard errors of the regression coefficients. Award and LIST are significantly positive related to EPDI at $1 \%$ alpha level $(\mathrm{p}$-value $=0.008<\mathrm{alph} a=0.01)$ and at $5 \%$ alpha level $(\mathrm{p}$-value $=0.034<\mathrm{alpha}=0.05)$, respectively. Award and LIST pass the significance test, so assumption 4 and assumption 7 are verified. SIZE and PLACE are positive related to EPDI, but SIZE (p-value $=0.122>$ alpha $=0.05$ ), and PLACE (p-value $=0.240>$ alpha $=0.05$ ) do not pass the significance test, so assumption 3 and 6 fail to be verified. However, the overall model is statistically significant because its freedom degree is equal to 7 and p-value is 0.000 , which is less than alpha being 0.01 .

Table 5: Estimation of Multivariate linear Regression Model

\begin{tabular}{l|l|l|l|l}
\hline Variable & Coefficient & SE & T-value & P-value \\
\hline Constant & -2.6858 & 0.8415 & -3.19 & 0.002 \\
\hline SIZE & 0.06001 & 0.03844 & 1.56 & 0.122 \\
\hline GROWTH & -0.01209 & 0.01476 & -0.82 & 0.415 \\
\hline EPS & -0.00919 & 0.05147 & -0.18 & 0.859 \\
\hline LogLEV & -0.00806 & 0.07152 & -0.11 & 0.911 \\
\hline AWARD & 0.22331 & 0.08283 & 2.70 & 0.008 \\
\hline LIST & 0.17523 & 0.08118 & 2.16 & 0.034 \\
\hline PLACE & 0.09132 & 0.07719 & 1.18 & 0.240 \\
\hline $\mathrm{F}=4.5 \quad \mathrm{R}^{2}=0.259$ Adjust $\mathrm{R}^{L=} 0.202$ & P-value $=0.000$ & & \\
\hline AS
\end{tabular}

As shown in Table 5, Growth, EPS, and $L E V$ have negative impact on environmental performance disclosure information, which is contrary to our original assumptions. They fail to pass the significance test, therefore, assumption 1,2 and 5 are not verified. One possible explanation could be that a company is not willing to disclose environmental performance information, which may be unfavorable to its development or profits. Investment in environmental protection will 
reduce profits of the company. For example, Yangnong chemical company deliberately concealed irregularities about environmental information and cheated Gates Foundation since 2009.

\section{Summary and conclusions}

More and more A-share listed companies of Chinese chemical industry disclose environmental performance information since 2007. The results show that EPDI level is critically low; Environmental award and listed place of companies are significantly positive correlated to EPDI. SIZE and PLACE of companies are positive correlation to EPDI, but fail to pass the significant test. The EPDI level of listed companies in SHSE is better than that of SZSE. The EPDI level of listed companies in the economically developed area is better than that of the others. However, GROWTH, $E P S$ and $L E V$ are negative correlation to EPDI, and also fail to pass the significant test.

Shanghai Stock Exchange and Shenzhen Stock Exchange promoted A-share listed companies to disclose social responsibility reports. However, disclosure proportion and level about environmental performance information was relatively low. No EPDI was certified by third-party verification. Only Wanwei Gaoxin completed reduction emission targets of Chinese Eleventh Five-Year, and was certified by the National Audit Office and provincial audit committee in 2010. EPDI is not high credibility. Huafeng Anlun disclosed CSR since 2008, accepted supervision by the public, opened pollution discharge and treatment, so increased the transparency of EPDI.

Environmental performance indicators of listed companies in Chinese chemical industry were quite different to $G 3$ standards. SHSE and SZSE can establish practical guidelines and manuals for the preparation of social responsibility reports by referring to international standards, regulate the preparation process of $C S R$, and promote environmental responsibility of listed companies.

\section{Acknowledgement}

This research was financially supported by Science Research fund of Hunan Provincial Education Department (Project No. 12C0111) and Hunan Provincial Natural Science Foundation of China(13JJ3090).

\section{References}

[1] Carrol A. B. A "Three-dimensional Conceptual Model of corporate performance", Academy of Management Review, 1979, 4,pp.497-505.

[2] James J. Brummer, "Corporate responsibility and legitimacy: an interdisciplinary analysis", Greenwood Press, 1991,pp.323.

[3] Ingram, Robert W, “An Investigation of the Information Content of (Certain) Social Responsibility Disclosures”, Journal of Accounting Research, 1978, 16(2), pp.270- 285.

[4] Guo P Y, "Porter's strategic model of corporate social responsibility", Sino Foreign Management, 2007, 10, pp.55.

[5] Shen H T, "Corporate characteristics and social disclosure-Evidencefrom listed companies in China", Accounting Research, 2007, 3,pp.9-16

[6] Pollution Probe, "Defining Corporate Environmental Responsibility: Canadian ENGO Perspectives", 2005,1,pp.26-30.

[7] Zhong C H; Gan S D, "Global Reporting Initiative and Sustainability Reporting Guidelines", Journal of Social Sciences, 2006, 9, pp.54-58 
[8] Peter M Clarkson, Yue Li, Gordon D Richardson, Florin P. Vasvari, "Revisiting the Relation Between Environmental Performance and Environmental Disclosure: An Empirical Analysis", Accounting Organizations and Society, 2008,33(4-5),pp. 303- 327.

[9] Tang J F, Li P F, “ Environmental Disclosure of Chemical Industry: Evidence from Chinese A: share Market", China Population, Resources and Environment, 2012, 5, pp. 112- 117.

[10] HE L M ,HOU T, "Determinants of Environmental Performance Information Disclosure in Chinese Listed Companies: Empirical Evidence Based on Social Responsibility Reports", China Population, Resources and Environment,2010, 8, pp.99-104.

[11] Carmelo Reverte. , "Institutional differences in EU countries and their relationship with earnings management differences: Implications for the pan-European stock market", Journal of Accounting \& Organizational Change. 2008, 4 (2), pp.182 - 200.

[12] Chen J G, “Chinese Corporate Social Responsibility Report(2010) ”,Beijing: Social Sciences Academic Press,2010. 